\title{
VULGARIOJI PUBLICISTIKA LIETUVOJE: KULTÜROLOGINĖ ŽANRO APŽVALGA
}

\section{Vulgarity Journalism in Lithuania: A Cultural Review of the Genre}

\author{
SUMMARY
}

An increasing amount of vulgarity is becoming more and more obvious in public social life as well as in individual behaviour. Vulgarity of speech is gradually becoming acceptable even in public discourse. The article aims at understanding the possible reasons of this socio-cultural trend, as well as establishing the terms of its theoretical analysis. The aim of this pilot research project is to introduce and define the Lithuanian term of "vulgarity journalism" in the attempt to explain its growing popularity, and to review the characteristic examples of linguistic vulgarity in public discourse. The reasons for vulgarisation of public discourse relate to the concept of the 20th century aesthetics of ugliness in culture. Review of examples from the Lithuanian context allows one to make a conclusion. The principal reasons for vulgarity in public discourse are aspirations to communicate criticism to the lowest social layers in a sarcastic manner. Language decorum is seen as an imposition and as an impediment to the freedom of expression/ thought of an individual who considers himself superior to his society.

\section{SANTRAUKA}

Vulgarumo įsigalëjimas dabarties kasdienybejje tampa vis akivaizdesnis tiek viešajame visuomeniniame gyvenime, tiek individų elgesyje. Kalbos vulgarumas, arba necenzūrinẻ leksika, pamažu tampa priimtinas net viešajame diskurse. Straipsnyje siekiama suprasti galimas šio kultūrinio pokyčio priežastis bei pagrịsti teorines problemos analizès prieigas. Šio pradinio pilotinio tyrimo tikslas - pristatyti ir apibrèžti lietuvišką "vulgariosios publicistikos" terminą siekiant paaiškinti jos auganti populiarumą bei apžvelgti būdingus viešojo diskurso kalbos vulgarumo pavyzdžius.

Viešojo diskurso vulgarejjimo priežastys straipsnyje siejamos su bjaurumo estetikos samprata XX a. kultūroje. Lietuviško konteksto pavyzdžių apžvalga leidžia daryti išvadą, kad viešosios kalbos vulgarumo 
pagrindinės priežastys yra siekis sarkastiškai komunikuoti žemiausiems socialiniams sluoksniams, reikšti kritiką ju atžvilgiu, siekis išsakyti visuomeninę kritiką apskritai arba siekis nepaisyti visuomeninių kalbos padorumo / vartojimo normų, kurios suvokiamos kaip primestos ir trukdančios individo, laikančio save pranašesniu už visuomenę, mąstymo / saviraiškos laisvei.

\section{IVADAS. SĄVOKŲ APIBRĖŽIMAS}

Vulgarioji publicistika nèra formalus publicistikos žanras, jos nerasime žurnalistikos žanru klasifikacijoje. Terminas aptiktas atsitiktinai, beskaitinejjant internetinius komentarus po žurnalisto A. Užkalnio straipsniu, jo autorius - nežinomas. Pasidomejjus šia tema anglakalbiuose kontekstuose darytina išvada, kad vulgarumo viešajame diskurse problematika tapo aktuali prieš kelerius metus, kai socialiniai tinklai įsiveržè i masiniu visuomenès informavimo priemoniu pasauli ir tiesiog išsprogdino ji savo leksika bei buitiškumu. Dauguma straipsniu internetiniuose portaluose ir tinklaraščiuose, skirtų vulgarumo temai, dažniausiai aptaria keiksmažodžiu vartojimą viešuose - paprastai rašytiniuose - pasisakymuose, transliuojamuose įvairiais mediju kanalais. Interpretacijos bei potemès labai ivairios - nuo psichologu išaiškinimo, kodèl žmonès keikiasi ir ar / kaip jiems tai naudinga, iki nuomonès, kad keiksmažodžių cenzūravimas pažeidžia kalbos laisvę.

Todèl dèl aiškumo galima imtis apibrèžimo, kad vulgarioji publicistika laikosi nuostatos, jog bet kokia cenzūra yra spaudos laisvejs pažeidimas, ir transliuoja autoriaus bei jo šaltinių nuomonę visiškai neredaguotą, su visais „autoriniais“ posakiais (t. y. keiksmažodžiais ir kitokia necenzūrine leksika).

Vulgarumo samprata vakarietiškoje kultūroje, bent jau lingvistiniu požiūriu, siejama su lotynų kalbos žodžiu „vulgaris“, reiškiančiu prieinamą visiems, visai tautai, visuotinį, žinomą ir paprastą ${ }^{1}$. Dabartinès lietuvių kalbos žodynas (toliau DLKŽ) pateikia dvi žodžio „vulgarus“ reikšmes: 1) šiurkštus, storžieviškas; 2) suprastintas, šiurkščiai iškraipytas ${ }^{2}$.

Kalbant apie vulgarumo sampratą apskritai, reikia pažymèti, kad ji gali būti labai ivvairi konkrečiose kultūrose - pavyzdžiui, ryškus moteru makiažas gali būti traktuojamas kaip vulgarus Vakaru visuomenèje, tačiau būti priimtinas tam tikrose Azijos šalyse, riaugèjimas traktuojamas kaip prasto tono požymis Vakaruose, o Kinijoje - tai pripažinimas šeimininkei apie maisto kokybę ir skonį. Apibendrintai galima teigti, kad vulgarumas iš esmès siejamas su tam tikrų tabu peržengimu, tabu, siejamu su minties, kalbos, elgesio, kūno fiziologijos normomis. Tarp tabu vyrauja lytiškumas, seksualumas, jo procesu nusakymas, antrasis pagal „nepadorumą" - nemalonių fiziologinių procesų (tuštinimasis, šlapinimasis, riaugèjimas ir pan.) apibūdinimas.

Kintant visuomenès sampratai, kas yra padoru ir kas - ne, kito ir vulgarumo suvokimas. Vakarietiška visuomenè išgyveno gana plačią draudimų ir padorumo ìvairovès skalę - nuo viduramžiško asketizmo iki renesansinio kūno kulto, klasicistinio formos grynumo, Viktorijos epochos padorumo išaukštinimo bei $X X$ a. žyminčio išsilaisvinimo iš daugy- 
bės iki tol vyravusių draudimų. XXI a. vakarietiškos visuomenès kontekste vulgarumo sąvoka - kaip niekada "kukli“. Kasdien visais mediju kanalais esame atakuojami daugybès vaizdinių, kuriems toli gražu nebūdingas santūrumas, o tabu peržengimo variacijos vertos atskiro straipsnio. Vis dèlto bandant apibrèžti XXI a. vulgarumo samprata, galima pasitelkti R. Barthes'o apmąstomą skirtumą tarp erotinès ir pornografinès fotografijos. Savo veikale apie fotografijos mediją Camera lucida: pastabos apie fotografija prancūzų teoretikas pateikia „unarinès fotografijos" apibrèžimą: fotografija tokia tampa, „kai ji empatiškai transformuoja "tikrovę" jos nesudvejindama, nepriversdama jos svyruoti, <...> jokio dvilypumo, jokio netiesioginumo, jokio trikdžio" ${ }^{\prime 3}$. Erotinè fotografija nèra vienalytè, joje vaizduojamas objektas nèra naivus, sužadina žiūrovo vaizduotę ir gali, anot Barthes'o, ji „,sužeisti“ (priversti mąstyti, ìsivaizduoti), o pornografinè unarinè - fotografija yra tarsi „vitrina, kuri demonstruoja tik vieną apšviestą brangenybę ${ }^{\prime 4}$. Čia nèra jokio antrinio objekto, kuris galètų atitraukti ar nukreipti žiūrovo dèmesị.

Taikant ši apibrèžimą vulgarumo sampratai XXI a. vakarietiškoje visuomenëje apskritai, galima teigti, jog vulgarumas prilygsta tiesmukumui, supaprastintam realybès pateikimui bei suvokimui, banaliam jos dokumentavimui, kuris, perfrazuojant Barthes'a, nepriverčia jos (realybès) svyruoti ir visada siekia vadinti daiktus ju tikraisiais vardais.

\section{VULGARUMAS KAIP SOCIALINĖS PADĖTIES KATEGORIJA}

Vulgarumas Vakarų kultūroje daugybę amžių buvo socialinès padèties rodiklis. Jau Antikoje tragedija buvo priskiriama "aukštajam menui“, vaizdavo dažniausiai aukštujjų visuomenès sluoksnių gyvenimą ir pasižymëjo tiek kalbos, tiek personažų rafinuotumu, o komedija, kurioje netrūko kūniškumo ir vulgarių (tiek antikine, tiek nūdienos prasme) pokštu (griuvimai, mušimai, stumdymaisi ir pan.), buvo skirta žemesniosioms visuomenès klasėms vaizduoti. Panaši vulgarumo samprata ir V. Šekspyro pjesèse komedijose netrūksta nešvankių juokeliu, veikiantys asmenys čia - dažniausiai vidurinio ar žemiausio luomo atstovai (pirkliai, jų šeimos nariai, jų tarnai, įvairūs amatininkai). Iki pat $X X$ a. pirmosios pusės elgesio, manieru bei kalbos vulgaru- mas griežtai siejamas su žemesne socialine padètimi. Svarbių visuomeninių pokyčių kontekste būtent kalbos vulgarumas (atspindintis mąstymo ippročius bei trajektorijas) signalizuoja asmens priklausomybę žemesniam sluoksniui, nors jo išvaizda, pajamos ir netgi manieros gali teigti priešingai. Arogantiškas požiūris i prasisiekèlius, nuvorišus ir „naujuosius piliečius" $X X$ a. pr. būdingas net JAV visuomenėje (puikus pavyzdys S. Fitzgeraldo romane „Didysis Getsbis“). Ryškiausiai vulgarumą pasmerkè karalienès Viktorijos epochos Anglija, o su ja - ir didžiosios Vakaru pasaulio dalies, kurią XIX a. valdè ši imperija, papročiai.

Tik didžiausios socialinès sumaišties laikotarpiais vulgarumas yra įsileidžiamas i „,aukštosios kultūros" terpę. Vienas 
ryškiausių pavyzdžiu - baroko epocha. XVI-XVII a. Europoje, persekiojamoje maro, karo ir bado, mirtis nuolat žvelgia žmogui i akis, o visuomeninio gyvenimo taisyklès susitraukia iki pagrindinès išgyventi. Gyvenimo trapumo suvokimas bei istoriniu pokyčiu inspiruotas augantis individualizmas kuria kontrastingą "katastrofos nuojautos kankinamą sąmonę ${ }^{\prime 5}$. Joje skleidžiasi nusivylimo dvasia ir "pasaulio beprotybès" tematika, ryškiai atsiverianti barokinio meno pavyzdžiuose: iškreiptose, nestabiliose, neproporcingose formose bei tradiciniu vertybiu parodijose. Vyraujančia išraiškos forma tampa ekscesas. Garbès sureikšminimas, perdètas jausmingumas, beribis seksualinis laisvumas ir nukrypimai nuo visu i̇manomų normų, fanatiškas skaistumo vaikymasis - šie ir kiti kontrastingi elementai sudaro baroko epochos visuomenini gyvenimą. Nuolatinè staigios mirties grèsmè bei visuotinis nerimas dèl ateities skatino nepaisyti draudimu bei tabu, siekti išgyvenimu ivairovès ir mėgautis beprotiškiausiomis aistromis. Maro akivaizdoje priklausymas kuriam nors socialiniam sluoksniui tapo ne toks svarbus, o išpopuliarèjusi karnavalu tradicija leido laisviau bendrauti visoms socialinėms klasėms. Tam tikra vulgarumo dozé - neatsiejamas karnavalo kultūros, ypač baroko epochoje, elementas.

Pažymètina, kad kai kurie tyrinètojai laiko baroką ne tiek chronologine-istorine, kiek kultūrine-ontologine sąvoka, žyminčia laikmečio pobūdị, panašiai kaip renesansas žymi kultūrinio atsinaujinimo idejją. Vienas ịtakingiausių baroko kultūros tyrinètojų $\mathrm{O}$. Calabrese teigia, jog barokas - tai tam tikrų ritminių, dinaminių kultūros struktūrų atsikartojimas, būdingų vidinių formų seka, aprèpianti epochos prieštaravimus į vientisa, unikalu audinį ${ }^{6}$. Toks laikotarpis, italu mokslininko teigimu, yra ir postmodernizmo epocha, kurią Calabrese siūlo vadinti neo-baroku (priešdèlis „,neo-“ implikuoja pakartotini jau pažistamos baroko epochos vaizdini).

Bet kuriuo atveju akivaizdu tai, jog abu šiuos laikotarpius sieja socialinè sumaištis. Vis dèlto kalbant apie postmoderno amžiu, būtina paminèti ir svarbiausią šio laikotarpio sumaišties „kaltininką" - elektros išradimą. Būtent jis, anot mediju teorijos pradininko M. McLuhano, perskrodė planetą nuo šiaurès iki pietų bei iš rytu i vakarus visomis kryptimis, užtvindydamas elektros medijomis tiek Vakaru žmones, tiek atokių vietų čiabuvius. Elektros atsiradimas ir technologiju plètra yra viena pagrindiniu europocentristinio mąstymo žlugimo, būdingo postmodernizmo epochai, priežasčių. Elektros greitis „,sumaišo priešistorès kultūras su industrinès prekeivių kultūros atmatomis, beraščius su pusiau raštingais ir jau neberaštingais ${ }^{47}$. Elektra ir ją naudojančios medijos vienodai greitai pasiekia visu civilizacijos lygmenu visuomenes tiek išsivysčiusius Vakarus, tiek jų kolonizuotas kultūras, tiek primityvias gentis. Vienas svarbiausiu postmodernizmo bruožu - padidẻjęs dėmesys ne Europos kultūroms, daugelis kurių tapo atradimu Vakaru visuomenei, bei kultūru lygiateisiškumo principo įtvirtinimas. Kita vertus, europocentristinès pasaulěžiūros žlugimas inicijavo kultūros hierarchiškumo nykimo procesą. Kitaip tariant, dau- 
gybę amžių egzistavusi skirtis tarp aukštosios ir žemosios kultūros èmė nykti, o interneto plitimas suteikè šiam procesui neitikètiną pagreitį.

Skirties tarp aukštosios ir žemosios kultūros nykimą bei masinio kultūros vartojimo pavojus aptarinejję Frankfurto mokyklos mąstytojai (ypač T. Adorno) prognozavo kultūros nuosmukị. Kultūros teoretiko Adorno teoriją gana dažnai linkstama suprastinti iki priešpriešos tarp „aukštosios" ir „žemosios“ kultūrų nusakymo ir "aukštosios“ kultūros gynimo nuo masių kultūros. Tai nèra visiška tiesa - nors Adorno simpatijos "aukštajai“ kultūrai akivaizdžios, jis pripažista neišvengiamą takoskyrą tarp elitinès ir masinès kultūros, ir mano, kad būtent ji yra šiuolaikinès kultūros egzistavimo sąlyga. Savo darbuose Adorno traktuoja populiariąją kultūrą kaip kultūros industriju produktą - tokiu būdu ji, kaip ir visi kiti kapitalistinès sistemos produktai, yra ideologinis masių noru ir poreikių valdymo (bei manipuliavimo jais) irankis ${ }^{8}$. Šie produktai (muzika, filmai, spektakliai ir kt.) nereikalauja iš žiūrovų maksima- laus susikaupimo visu pirma dèl to, kad jie yra "tuščiaviduriai“, lèkšto turinio, o jų vertę lemia reklamos kampanijai išleistų pinigų kiekis. Jie ne tik neskatina mąstyti, priešingai, blokuoja mąstymą apskritai. Populiarioji kultūra yra „vartojama" kaip bet kuris kitas produktas, o tai atliekantis individas „degraduoja", nes tam, kad išgyventų kultūrinę patirti (patirtų katarsi), jam nereikia jokio susikaupimo. Arba, kaip pasakytų Barthes'as, jam nereikia jokio dvilypumo, jokio netiesioginumo, jokio trikdžio.

Tokiu būdu kultūra praranda savo tradicinę kilninančią vertę ir tampa dar viena preke, kurios tikslas - būti parduotai. Tam tinka visos reklamos ir rinkodaros strategijos bei taktikos, o kultūros išskirtinumas nyksta kartu su skirtimi tarp „aukštojo“ (tauraus, kilninančio) ir „žemojo“ arba masių (pramoginio, linksminančio) kultūrinių sluoksnių. Pateikdamos pramogą kaip taurinantị veiksmą, kultūrinės industrijos, anot Adorno, vykdo kultūros sudaiktinima, o tai, kritiko nuomone, yra ne kas kita kaip apgavystè9.

\section{VULGARUMAS IR BJAURUMO ESTETIKOS ASPEKTAI}

Galima teigti, jog kultūros sudaiktinimo tendenciją iš dalies patvirtina nuo $X X$ a. vidurio agresyviai sau kelią Vakarų kultūroje besiskinanti bjaurumo estetika. Filosofas A. Šliogeris ją apibūdina kaip „bandymą advokatauti šètonui“"10, o šiuolaikini meną - antimenu ${ }^{11}$. Mąstytojas teigia, jog anksčiau buvo neatskiriami menas ir grožis, o dabar "sulipdomi menas ir bjaurastis“, "[m]enas virto šètono imperija"12.
Pirmoji bjaurumo kaip estetinès kategorijos studija pasirodè dar 1853 m., jos autorius K. Rosenkranzas sistemiškai tyrinejjo bjaurumo problemą meno estetikos kontekste. Ikvèptas Hegelio estetikos sampratos, Rozenkranzas teigia, kad tik aukštesniam estetiniam grožiui pajungtas bjaurumas yra priimtinas mene. Savo veikale Bjaurumo estetika Rozenkranzas nagrinèja ryši tarp grožio ir bjaurumo, prieidamas prie išvados, jog bjaurumas me- 
ne būtinas kaip grožio simetrijos elementas. Bjaurumas yra neatsiejamas nuo grožio dialektine prasme, nes kiekvienoje sąvokoje slypi jos paneigimas - taigi, grožio prigimtyje slypi bjaurumas kaip ji (grožì) išryškinantis kontrastas ${ }^{13}$. Kitaip tariant, grožis igauna savo turinį tik dèl jame slypinčio bjaurumo.

$X X$ a. pr. bjaurumo estetiką toliau nagrinejjo kitas Hegelio sekejjas B. Bosanquet. Trijose paskaitose apie estetika jis išryškina skirti tarp gamtos ir meno, tokiu būdu patvirtindamas meno autonomiją ${ }^{14}$. Autorius teigia, jog bjaurumas estetine prasme nagrinètinas tik tuo atveju, jei jis nukreipia i groži. Kitaip tariant, bjaurumas irgi gali būti suvokiamas kaip grožio išraiška. Rozenkranzas manė, jog bjaurumas mene gali atsirasti tik kaip kontrastas grožiui, Bosanquet tvirtina, kad bjaurus objektas gali būti pateikiamas meno kūrinyje pats vienas, be grožio objekto, kuris kurtų kontrasta, išryškinanti groži / bjaurumą ${ }^{15}$. Bosanquet idiegia sąvoką "komplikuotas grožis" (difficult beauty), kurią priešina „paprasto grožio“ (simple beauty) sąvokai. „Komplikuotas grožis" apibūdina rafinuotus meno kūrinius, reikalaujančius iš žiūrovo tam tikro išlavinto estetikos pojūčio. Tik apsišvietęs žiūrovas gali suvokti tokio „komplikuoto grožio“ meno kūrinius, o tai, kad tam reikalingas atitinkamas išsilavinimas, nereiškia meno kūrinio ydingumo. Čia kyla išvada, būdinga visai $X X$ a. pr. modernizmo estetikai: visos meno išraiškos formos yra gražios, ir tik žiūrovų išsilavinimo trūkumas gali trukdyti tą groži ižzelgti. Kitaip tariant, akcentuojamas meno elitiškumo aspektas. Jis pabrèžia būtinybę publikai turèti tam tikrą estetinį / menini / literatūrini išsilavinimą, be kurio meninès išraiškos formos jai bus nesuvokiamos.

Tiek Rozenkranzas, tiek Bosanquet suvokia bjaurumą kaip grožio neigimo būdą. Tuo tarpu jau minètas Adorno apverčia ši santyki teigdamas, kad pirma buvo bjaurumas ir tik tada atsirado grožis: „Jei vienas atsirado iš kito, tai grožis kilo iš bjaurumo, o ne atvirkščiai. "16 Adorno i grožio sampratą žvelgia chronologiškai, nuo archaiško, primityvaus meno pereidamas prie vėlesnių, kultūriškesnių meno formų. Net rafinuočiausias menas, Adorno teigimu, išsaugo tam tikrą ryši su primityviosiomis savo šaknimis ir tokiu būdu tampa suvaržančiu prigimti / gamtą. Bjaurumas šiame kontekste yra archaiško, primityvaus sinonimas - to, ko menas, kaip nušviečianti jèga, stengiasi išvengti ${ }^{17}$. Tačiau bjaurumas taip pat teigia gyvenimo pergalę prieš estetinės formos mirtį. Taigi i meno istoriją Adorno žvelgia kaip ì dialektinę modernaus ir archaiško sampyną.

Tačiau, kaip teigia kritikas V. Bachmetjevas, svarbiausia Adorno teorijoje yra socialinis bjaurumo mene aspektas. Bjaurumo sąvoka visuomenèje iškyla sąryšyje su draudimų bei tabu kompleksu. Anot Adorno, „menas turi užsistoti tai, kas suvokiama kaip bjaurumas" ${ }^{\prime 18}$. Tai yra „menas turi pasinaudoti bjaurumu tam, kad paneigtu pasauli, kurianti ir vaizduojanti bjaurumą pagal savo atvaizdą“19. Todèl meno užduotis - būti tų socialinių reiškinių pusèje, kurie traktuojami visuomenejje kaip tabu. Bjaurumas mene tik padidina meno svarbą ir pasipriešinimą esamai padėčiai. Tai ypač aktualu šiuolaikiniam menui ${ }^{20}$. Moder- 
naus meno užduotis - būti toje socialinių reiškinių pusejje, kurie yra laikomi tabu. Kritinė modernaus meno kūrinio funkcija, ypač jo opozicija esamai padéčiai (status quo), remiasi ir galima tik bjaurumo atvaizdavimu ${ }^{21}$.

Viena vertus, šiuolaikinio meno kūriniai tarsi patvirtina šią Adorno teoriją. Tabu peržengimas - viena iš kertiniu taisyklių menininkui, jei jis nori būti pastebètas vartotojiškoje visko - taip pat ir meno - pertekusioje vakarietiškoje kultūroje. Negyvi drugeliai, išmatos, neklota lova su nuorūkomis ir panaudotais prezervatyvais - tai tik keletas pavyzdžių iš ryškiausiomis XXI a. meno asmenybėmis laikomų kūrèjų arsenalo. Kita vertus, vargu ar būtent tokị tabu peržengimo aspektą turejo omenyje Adorno, formuluodamas savają estetikos teoriją.

Vis dèlto galima drąsiai teigti, jog estetine prasme vulgarioji publicistika neabejotinai artima „bjaurumo estetikos“ sąvokai, kuri dažnai ir izvairiuose kontekstuose siejama su daugeliu postmodernistinio meno vardų (tokių kaip Damien Hirst, Andres Serrano, broliai Jake ir Dinos Chapman, Tracey Emin ir kt.)

\section{VULGARIOJI PUBLICISTIKA LIETUVOJE}

O dèl kalbos vulgarumo, Vakarų pasaulyje daugmaž sutariama, kad ji, tarp kitų, reprezentuoja keiksmažodžiai ir kiti nepadorūs žodžiai, kurių nedera vartoti viešumoje: „dauguma keiksmažodžių siejasi su lytiniais organais, lytiniais santykiais, išmatomis ar kitais tabu, ir yra vartojami skirtingais tikslais: izžeisti, pažeminti žmogų; kaip neigiamų emocijų jaustukas; kaip neigiamą atspalvi kokiam nors elgesiui suteikiantis žodis; kaip vaizdingo pasakymo dalis nekultūringoje kalboje; kaip stilistinè priemonè grožinejje literatūroje ar meniniuose filmuose perduodant tam tikrų socialinių sluoksnių ar grupių specifiką“22.

Tiek keiksmažodžiai, tiek nešvanki leksika yra natūrali daugelio kalbų dalis, kuriai skiriamos solidžios studijos, sudarinejjami žargono, gatvès kalbos ir pan. žodynai. Tačiau lietuvių kalba šio pobūdžio tyrimų kol kas yra nedaug (žinomiausia šios srities tyrinètoja Lietuvoje Danguolè Melnikienè), o žargono žody- nas dažniausiai suprantamas kaip vienos ar kitos profesinès srities terminų visuma (pvz., teisès ar medicinos). Šio pobūdžio leidinių netrūksta (teisès, medicinos, draudimo, turizmo, ekonomikos, spaudos, fotografijos terminų žodynai, ir pan.). O išsamesnių gatvès kalbos registravimo būdų turime vos vieną kitą pavyzdi. Dažniausia tai internetiniai "gatvės" terminų sąrašai, pvz., gatvės žargonų žodynèlis ${ }^{23}$ arba "Jaunimo žargonų žodynèlis“24. Internete galima aptikti ir rimtų šaltinių, tokių kaip VU Filologijos fakulteto sudaryta žargono bazè (nurodoma, kad ji publikuota 2010 m.). Kol kas solidžiausi šio pobūdžio veikalai - Roberto Kudirkos sudaryti žodynai: Lietuviu kalbos žargono ir nenorminés leksikos žodynas (Kaunas: Technologija, 2012) bei $\mathrm{Ka}$ lejimo, kriminalinio ir narkomanu žargono žodynas (Kaunas: Kitos knygos, 2012 ir 2014 m. leidimai).

Dėmesio trūkumą šiai kasdienės kalbos sričiai literatūros vertèja Irena Bal- 
čiūnienė aiškina sovietmečio palikimu, kai necenzūrinè leksika tiek viešajame diskurse, tiek literatūroje buvo uždrausta. Balčiūnienè užsimena apie labai įdomią keiksmažodžiu ir nešvankios kalbos vertimo problemą, su kuria sovietmečiu susidurdavo knygų vertejai: kaip autentiškai perteikti necenzūrinę leksiką gimtaja lietuvių kalba visokeriopos cenzūros sąlygomis?25 Tai vienas iš specifiniu šios tekstinès komunikacijos rūšies (t. y. necenzūrinès leksikos) ypatumu, aktualus ne tik kultūru bendradarbiavimo (taip būtu galima ịvardinti literatūrinius vertimus), bet ir tiesioginès sąveikos sąlygomis. Kitaip sakant, vulgarioji publicistika (tiek kaip žanras, tiek kaip literatūrinio ar kitokio teksto savybè) yra ypatingai glaudžiai susijusi su savo kultūra. Jeigu bet kurio kito žanro straipsniai užsienio auditorijai yra laisvai prieinami (t. y. suprantami) - jei tik pastaroji moka atitinkamą kalba - tai vulgariosios publicistikos priesakų besilaikančio autoriaus tekstai ir jų minties ypatumai bus visiškai suprantami tik ypač gerai (aptariamą) kalbą ịvaldžiusiems užsienio piliečiams.

Pažymètina, jog tiek vulgarumo, tiek bjaurumo estetika nėra nežinoma lietuvių kultūrai. Apie ją išsamiai kalba filosofas Šliogeris („,Pokalbiai apie esmes“), ryškūs pavyzdžiai aptinkami tiek literatūroje, tiek mene, tiek dramaturgijoje, tiek kinematografijoje, ypač šiuolaikinėje. Svarbu tai, jog ryškiausias kultūriniame Lietuvos diskurse yra būtent kalbos vulgarumo aspektas. Vienas idomesniu pavyzdžiu - pagal M. Ivaškevičiaus pjesę pastatytas O. Koršunovo spektaklis „Išvarymas“, kuris savo laiku tapo dideliu iššūkiu tradicinei Lietuvoje vyravusiai teatro scenos kaip šventovẻs traktuotei. Ivaškevičiaus ir Koršunovo herojai scenoje keikiasi taip, kad jautresni žiūrovą gali ir supykinti. Tačiau šiu pastarụjų likę, matyt, nedaug, nes į spektakli, pastatytą $2011 \mathrm{~m}$., bilietus vis dar reikia pirkti prieš kelis mènesius. Ryškiausias kinematografo pavyzdys - režisieriaus E. Vèlyvio filmai: visos „Zero“ serijos ir, žinoma, „Redirected“. Dèl pastarajame iškylančio Lietuvos paveikslo iki šiol verda aistros tarp manančių, kad tẻvynę vaizduoti kaip degradu šali yra tiesiog negalima, ir tu, kurie galvoja, kad tiesa yra svarbiau už patriotizmą. Kitas pavyzdys galètu būti (šiuo metu vis mažiau populiarus) viešo anekdotu pasakojimo žanras, kurio lyderiai - R. Šilanskas ir R. Bingelis, vadinamają "užstalès kultūrą" kadaise iškèlę i televizines aukštumas. Čia priskirtina ir jo modernesnè, vakarietiška versija - stand-up pasirodymai, kurie neatsiejami nuo vulgarumo estetikos, ir be jos, ko gero, negalètu egzistuoti tiek Vakaruose, tiek Lietuvoje.

Kalbant apie vulgariosios publicistikos atvejus viešajame diskurse, reikia pabrèžti, kad šis žanras vis delto nèra formalus, todèl „oficialiosios“ žiniasklaidos priemonėse jo pavyzdžiu ieškoti neverta (su tam tikromis išimtimis, kurios bus iš dalies aptartos vèliau). Vulgariosios publicistikos perlu gausu naujosios žurnalistikos „leidiniuose“ - asmeniniuose internetiniuose tinklaraščiuose, kuriems, beje, pranašaujama šviesi visuomenès informavimo priemonių revoliucionierių ateitis. 
Reikia pažymèti, jog ši tendencija ryški daugelyje Vakarų kultūrų: mados, maisto bei kelionių tinklaraštininkai jau keletą metų yra tarp ittakingiausių „nuomonių formuotojų“. Idomiausia tai, kad daugeli ìtakingiausių tinklaraštininkų Lietuvoje sieja būtent kalbos vulgarumo aspektas. Šia prasme visų pirma minètina žanro „pionieriaus“ žurnalisto A. Užkalnio pavardè, taip pat necenzūriniais savo pasisakymais pagarsejusi stiliste A. Jagelavičiūtè bei tiesiog Rokiškio Rabinovičiaus vardu žinomas tinklaraštininkas (už jo slepiasi buvęs žurnalistas, dabar IT sferoje dirbantis R. Savukynas). Vis dèlto vulgarumo apologetu Lietuvos viešajame diskurse apskritai turètų būti laikomas TV ir radijo laidų vedejjas A. Ramanauskas-Greitai. Nors pats autorius savo vartojamą leksiką yra linkęs sieti visų pirma su savo kuriamais ironiškais, sarkastiškais nepraustaburniais personažais, tačiau, analizuojant jo pasisakymus raštu bei jo publikuojamus tekstus, kyla pagrista abejonè, kad eilinis skaitytojas galètų lengvai atskirti pati autorių nuo jo kuriamo personažo. Juolab kad pats Ramanauskas-Greitai šalia profesinių apibūdinimų „TV laidų vedejjas, aktorius, režisierius, scenaristas bei muzikantas“ apie save pateikia ir kitus: „storžievis, ekscentrikas ir išgama“26. Ramanausko sukurti personažai išpopuliarino viešajame diskurse daugelị lietuvių kalbos žodžių, kurių anksčiau padoriais save laikantys kalbètojai buvo linkę vengti: „debilas”, „,išgama“, „,̌̌lykštynè", „mèšlas", „išsigimèlis“ ir kt.

Pažymėtina, jog kalbos vulgarumas Lietuvoje tampa vis labiau isigalinčia norma, ypač socialinių tinklų erdvėje, kurioje gana lengva apsigauti privatumo iliuzija. Jei minètiesiems Užkalniui, Jagelavičiūtei bei kai kurioms kitoms garsenybėms savo tinklaraščiuose dažnai pavyksta vulgarumo išvengti, tai socialiniu tinkle paskyrose jie leidžia sau viską. Konkrečių pavyzdžių aptarimui reikètú atskiro straipsnio. Šiame tekste pakaks pateikti keletą apibendrinimų apie minimų autorių stilių bei jo vartojimo priežastis, kurias galima numanyti iš šių autorių interviu bei viešų pasisakymų.

Viena dažniausiai deklaruojamų vulgarios leksikos vartojimo priežasčių siekis kalbèti tam tikram socialiniam sluoksniui suprantama kalba. Ramanauskas-Greitai, kartu su kolega R. Šapausku vadinami juodojo humoro pradininkais Lietuvoje, ivvairiuose interviu pabrèžia, kad jo kuriami nešvankūs personažai yra skirti sovietinio mentaliteto palikuonims išjuokti. Anot TV laidų vedèjo, tik tokiu būdu ši socialinè grupè sugeba pažvelgti i save iš šalies ir pradèti suvokti savo trūkumus. Tuo tarpu aukštesnių socialinių sluoksnių atstovai nesunkiai supranta šio pobūdžio humorą ir traktuoja ji kaip sarkazmą (kuris iš esmės yra kiekvienos išsivysčiusios kultūros dalis). Tikriausiai būtent taip reikètų suprasti Ramanausko-Greitai tekstus alfa.lt portale, pavyzdžiui:

Kai Viešpats kūrè pasauli, jis tai padarè per šešias dienas, kaip koks purvinkiaušis santechnikas, kuriam nepakanka vienos. Septintą dieną, žinia, Viešpats uliavojo su būzu ir pigiais narkotikais. Turiu rimtų itarimų kad Overlordas ir savo darbo dienomis darbavosi su kvapeliu, 
nes sukurti tai, ką jis „,sukūrè , imanoma tik ant acetoninès starkos su Uspaskicho karnišonais. $^{27}$

Ne toks šiurkštus, tačiau taip pat ryškus sarkazmas akivaizdus Užkalnio tekstuose, kurių pirminė paskirtis - taip pat tam tikra socialinè kritika, vykdoma irgi populiariosios kultūros kontekstuose (maisto, kelionių, kultūrinių skirtumų ir pan. tematika). Tiesmukiški vertinimai ir daiktų vadinimas tikraisiais vardais, nevengiant keiksmažodžių ar padorioje draugijoje nevartotinų žodžių, leidžia spèti, jog Užkalnio tekstai yra skirti „garui nuleisti“ - tai dar viena dažniausiai minimų vulgariosios leksikos vartojimo priežasčių. Pavyzdžiai iš Užkalnio tekstų feisbuke:

Labai patinka karštis? Prikaitink orkaitę, atsidaryk, atsisèsk ir priremk galvą kuo arčiau, gal pajusi malonumą. Arba užsiklok penkiom kaldrom ir pajusk savo asmeninę prakaituota, susmirdusią vasarą. Tiesą sakant, daugelis taip ir daro. Todèl ju butai ir dvokia. ${ }^{28}$

DARBO AUKOS. <...> Čia tie, kurie, kai atidaro burna, pradeda kalbèt, kaip jiems blogai darbe, debilas viršininkas, jų nevertina, algą kelia ne tiems, kam reikia, projektus laimina ne tuos, ir išvis, komandiruotes gauna ta kurva Laura, ir visi žino, kad ji čiulpia viršininkui. Šitiems gali kuolą tašyt ant galvos. ${ }^{29}$

Jau seniai esu sakęs, kad lietuvių liguistas domejjimasis politika, Seimo narių atlyginimais, dabar jau - ir meilužiuc autotransportu yra itin ydingas iprotis. Kaip smirdinčių kūno dalių uostymas. Rakinejji kojų tarpupirščius ir uostai pirštus. Ir dar juokus apie tai darai, visokias dvyračio žynias, nes yra pakankamai acto prisigaravusių iškrypèlių, kuriems irgi patinka pakalbėti apie tarpupirščių uostymą. ${ }^{30}$

Vienas i̊domesnių - stilistės A. Jagelavičiūtès atvejis. Jos îsteigtame stiliaus patarimų portalo STILIUSOS bloge bei asmeniniuose feisbuko įrašuose publikuojami tekstai niekuo neišsiskiria ir dažnai yra visiškai padorūs. Tačiau komentarų skiltyje stilistė demonstruoja, kad vienas jos mėgstamiausių užsièmimų, kaip pati sako, „pasibarti“ (nors čia turbūt labiau tiktų žodis "pasikolioti“). Štai, pavyzdžiui, reakcija i vienos skaitytojos komentarą dèl neva netikro konkurso laimèti dovaną:

Agne Jagelaviciute „Ka tu nori pasakyti tuo „niekas nieko nedovanos“, ispurtus idiote? Dar cia straipniu numeriukais operuoja silpnaprote. Kaip taisykle, kuo didesnis dvasios ubagas, tuo labiau visus gasdina. ${ }^{\text {31 }}$

Atsakymas i kažkurią kitokio pobūdžio kritiką - dar tiesmukiškesnis:

Agne Jagelaviciute "Si karta asmeninis tekstukas: Pasla nx. ${ }^{\text {32 }}$

Pažymėtina, kad dar neseniai vulgariais laikytu, tačiau šiuo metu beveik neutraliais tapusių žodžių "šūdas", "šikna", „nusišikt", „papai," „subinè" bei pan. vartojimas socialiniuose tinkluose yra norma, o tam tikra jų „vieša legitimizacija" vyksta nuolat. Kaip pavyzdi galima pateikti populiaraus interneto komentatoriaus L. Andriulio pranešimą LOGIN 2017 konferencijoje „Š̄ūdas tas tavo startupas". Andriulio tekstai, beje, taip pat bent iš dalies priskirtini vulgariosios publicistikos kategorijai - juose netrūksta nei keiksmažodžių, nei vulgarokų posakių. Šio autoriaus tekstų vulgarumo tikè- 
tina priežastimi gali būti asmeninè jo gyvenimo istorija, kuri anglakalbiame pasaulyje būtų apibendrinta kaip ,from rags to riches" ${ }^{\prime 33}$. Nuo nulio prabangų bei ispūdingą gyvenimą susikūręs žmogus gali sau leisti nekreipti dèmesio i standartiniam piliečiui keliamus reikalavimus, todèl šiuo atveju kalbos vulgarumas gali būti suvokiamas kaip laisvės ir normų nepaisymo - tabu sulaužymo išraiška. Platesne prasme tai galètų būti traktuojama kaip pasipriešinimo visuomenès primetamoms taisyklems forma, arba tam tikras asmeninis protestas pries visuomeninius lūkesčius, keliamus kurios nors profesijos, išsilavinimo žmonėms.

\section{IŠVADOS}

Reziumuojant reikia pasakyti, kad vulgarumas XXI a. kultūroje apskritai traktuotinas kaip socialinès sumaišties laikotarpio požymis ir sietinas su bjaurumo estetikos įsigalejjimu vakarietiškoje pasaulěžiūroje. Vulgarioji publicistika neformalus žanras, agresyviai besiskinantis sau kelią šiuolaikinëje žiniasklaidoje. Šiuolaikinè vulgarumo kaip sąvokos reikšmès interpretacija turètų būti siejama su masine kultūra - t. y. terminas „vulgarus" turètų būti siejamas su masinio vartojimo kultūros atributais. Vulgarioji publicistika atitinka būtent ši apibrèžimą - savo kritikams autoriai atkerta, jog specialiai rašo tokiu stiliumi, kad jis būtų priimtinas „masiniam“ skaitytojui.

Vulgarioji publicistika Lietuvoje vartojama dèl triju pagrindinių priežasčių: noro pasiekti žemiausius socialinius sluoksnius (todèl pasirenkama kalbèti jiems suprantama kalba) bei sarkastiškai atvaizduoti ju mąstyma, tikintis, kad tokiu būdu jie sugebės pažvelgti i save kritiškai; kaip tam tikro pobūdžio socialinès kritikos instrumentas; kaip visuomenès primestų normų nepaisymo ir mąstymo / saviraiškos laisvès išraiška. Ryškiausi vulgariosios publicistikos pa- vyzdžiai aptinkami socialiniuose tinkluose bei asmeniniuose tinklaraščiuose, o jų autoriai gali būti tiek realūs žmonès, tiek išgalvoti personažai, kurių paskirtis dažnai būna kritikuoti tą socialinį sluoksni, kuriam ju publicistika yra skirta.

O ì natūraliai kylantị klausimą, ar vulgarumas viešumoje yra pasekmè, ar priežastis, tikriausiai reikètų atsakyti platesnèje diskusijoje, tačiau akivaizdu, kad ši tendencija gyvybinga įvairiose XXI a. kultūros formose, ir kad ji neketina trauktis. Politiniai bei visuomeniniai pastarojo meto izvykiai - ypač D. Trumpo išrinkimas JAV prezidentu - skatina susimąstyti apie vulgarumo kaip tam tikros mąstymo kategorijos formavimąsi. Politikos apžvalgininkai aiškina Trumpo pergalę kaip savotišką maišto prieš reglamentuotą visuomeninę hierarchinę hegemoniją išraišką Vakaruose. Naujojo JAV prezidento nesivaržymas ir visuotinai priimtų, savaime suprantamų korektiško elgesio normų nepaisymas - paprastai tariant, chamizmas, leidžia daryti prielaida, kad vulgarumas tapo naujuoju standartu. Vulgarioji publicistika buvo - yra - laikotarpio ženklas ir žymè. 


\section{Literatūra ir nuorodos}

1 <http://www.zodziai.lt/reiksme\&word=Vulgaru s\&wid=20862>[žiūrèta 201708 10]

2 <http://lkiis.lki.lt/> [žiūrèta 201708 10]

3 Roland Barthes, Camera lucida: pastabos apie fotografija. Kaunas: Kitos knygos, 2012, p. 54.

4 Ten pat, p. 55.

5 J. A. Maravall, Culture of the Baroque: Analysis of a Historical Structure. Manchester: Manchester University Press, 1986, p. 149.

6 Omar Calabrese, Neo-Baroque: A Sign of the Times. Vert. Ch. Lambert. Princeton: Princeton University Press, 1992, p. 5-15.

7 Marshall McLuhan, Kaip suprasti medijas: žmogaus tęsiniai. Vilnius: Baltos lankos, 2003, p. 34.

8 Žr. Allan How, Critical Theory. Hampshire: Palgrave Macmillan, 2003, p. 75.

9 Žr. T. Adorno, 'The Culture Industry: Enlightenment as Mass Deception'.

10 Arvydas Šliogeris ir Virginijus Gustas, Pokalbiai apie esmes. Vilnius: Tyto alba, 2013, p. 291.

11 Ten pat, p. 292.

12 Ten pat.

13 Viktoras Bachmetjevas, "The Ugly in Art". Žmogus ir žodis, IV, 2007, p. 31.

14 Bachmetjevas, p. 32.

15 Ten pat.

16 Th.W. Adorno, Aesthetic Theory. Vert. C. Lenhardt, red. Gretel Adorno ir Rolf Tiedemann. London Boston, Routledge \& Kegan Paul, 1984, p. 75.

17 Bachmetjevas, p. 33.

18 Adorno, p. 72.

19 Ten pat.

20 Bachmetjevas, p. 34.
21 Ten pat.

22 <https://lt.wikipedia.org/wiki/Keiksma\%C5\%BEodis> [žiūrèta 201708 21].

23 Puslapyje ltvirtove.lt, <http://www.ltvirtove.lt/ zodynai.php?lt=gatves_zargonu_zodynas $>$ [žiūrèta 201706 23]

24 Skelbiamas Lietuvos geografijos mokytojų internetiniame puslapyje, <http:/geografija.lt/2009/10/ jaunimo-zargonu-zodynelis> [žriūrèta 201706 23]

25 Irena Balčiūnienè, Keiksmažodžių vertimas. Pranešimas, skaitytas LLVS seminare-diskusijoje 200612 06, <http://www.llvs.lt/?recensions= 229> [žiūrèta 201708 22].

$26<$ https:/www.elaima.lt/naujiena/laimos-veidai/ algis-ramanauskas-greitai-as-esu-daugybiniszmogus-846-754196> [žiūrèta 201705 29]

27 <http://www.alfa.lt/straipsnis/50180887/gamtamusu-konclageris> [žiūrèta 201708 22]

$28<$ http://protokolai.com/2017/06/06/uzdrauskitvasara/> [žr 201708 22]

$29<$ https://www.facebook.com/permalink.php?sto ryfbid $=448557015526302 \&$ id $=146293139086026 \&$ substory_index=0> [žiūrèta 201708 22]

$30<$ https://www.facebook.com/permalink.php?sto ryfbid $=447177958997541 \&$ id $=146293139086026 \&$ substory_index=0> [žiūrèta 201708 22]

$31<$ https://www.facebook.com/agnejagelaviciutestilius/posts/900439813438480 > [žiūrèta 201708 22]

$32<$ https://www.facebook.com/agnejagelaviciutestilius/posts/900439813439340> [žiūrèta 201708 22]

$33<$ http://www.delfi.lt/news/ringas/lit/l-andriulisvaikai-pakalbekime-apie-pinigus.d?id=74300734> [žiūrèta 201707 18] 